\title{
Biology and Impacts of Pacific Island Invasive Species. 4. Verbesina encelioides, Golden Crownbeard (Magnoliopsida: Asteraceae) ${ }^{1}$
}

\author{
Katbleen R. Feenstra ${ }^{2}$ and David R. Clements $^{2,3}$
}

\begin{abstract}
Verbesina encelioides (Cav.) Benth. \& Hook. f. ex A. Gray, golden crownbeard, is a sunflower-like herbaceous annual plant ranging in height from 0.3 to $1.7 \mathrm{~m}$ with showy yellow flowers. It is native to the southwestern United States, the Mexican Plateau, and other parts of tropical America. Its invasive characteristics include high seed production (as many as 300-350 seeds per flower and multiple flowers per plant), seed dormancy, ability to tolerate dry conditions, and possible allelopathic effects. Disturbed areas with a relatively sandy substrate within warm, arid climate zones are vulnerable to invasion by $V$. encelioides. Verbesina encelioides is found on all of the main Hawaiian islands except $\mathrm{Ni}$ ihau but is particularly problematic on Midway and Kure Atoll, where it may threaten the habitat of nesting birds such as Laysan and black-footed albatrosses and Christmas and wedge-tailed shearwaters. Many other Pacific islands with similar habitats could be invaded by $V$. encelioides. The plant has become naturalized in many other U.S. states, parts of South America, the Bahamas, Cuba, the Dominican Republic, Puerto Rico, parts of Europe, Saudi Arabia, India, Ethiopia, Morocco, Botswana, Namibia, Israel, and Australia. It is a pest of various crops in the southern United States and India and is poisonous to sheep and cattle. Verbesina encelioides can be controlled via herbicides or mechanical means, but measures must be repeated due to the presence of persistent seed banks. Further research on $V$. encelioides is needed to understand its population dynamics, allelopathic properties, and impacts on natural ecosystems.
\end{abstract}

Golden crownbeard, Verbesina encelioides (Cav.) Benth. \& Hook. f. ex A. Gray is an herbaceous annual plant first known to invade the Pacific islands in the nineteenth century (Whistler 1995, Carr 2006). The plant now occupies all of the main Hawaiian Islands except Ni'ihau (Wagner et al. 2005). Its increasing spread on the Hawaiian Islands, particularly on the northwestern islands such as Kure and Midway Atoll, has been cause for alarm because it appears to lower habitat

${ }^{1}$ This research was supported by Trinity Western University and a Weed Science Society of America undergraduate award to K.R.F. Manuscript accepted 2 July 2007.

${ }^{2}$ Department of Biology, Trinity Western University, Langley, British Columbia, Canada V2Y 1Y1.

${ }_{3}^{3}$ Corresponding author (e-mail: clements@twu.ca).

Pacific Science (2008), vol. 62, no. 2:161-176

(C) 2008 by University of Hawai'i Press

All rights reserved quality for ground-nesting birds (Shluker 2002). Because $V$. encelioides possesses numerous invasive characteristics and has already invaded many other parts of the world, it is important to develop a comprehensive understanding of the plant to limit its spread within Hawai'i and prevent invasion of other Pacific island ecosystems. The biology and impact of $V$. encelioides was reviewed by Shluker (2002); the current review provides an updated and more comprehensive account.

NAME

Verbesina encelioides (Cav.) Benth. \& Hook. f. ex A. Gray

Synonym: Ximenesia encelioides Cav. Subspecies: Verbesina encelioides subsp. encelioides; Verbesina encelioides subsp. exauriculata (B. L. Rob. \& Greenm.) J. R. Coleman

Phylum Angiospermae, class Magnoliopsida, order Asterales, family Asteraceae, tribe Heliantheae, genus Verbesina L. 

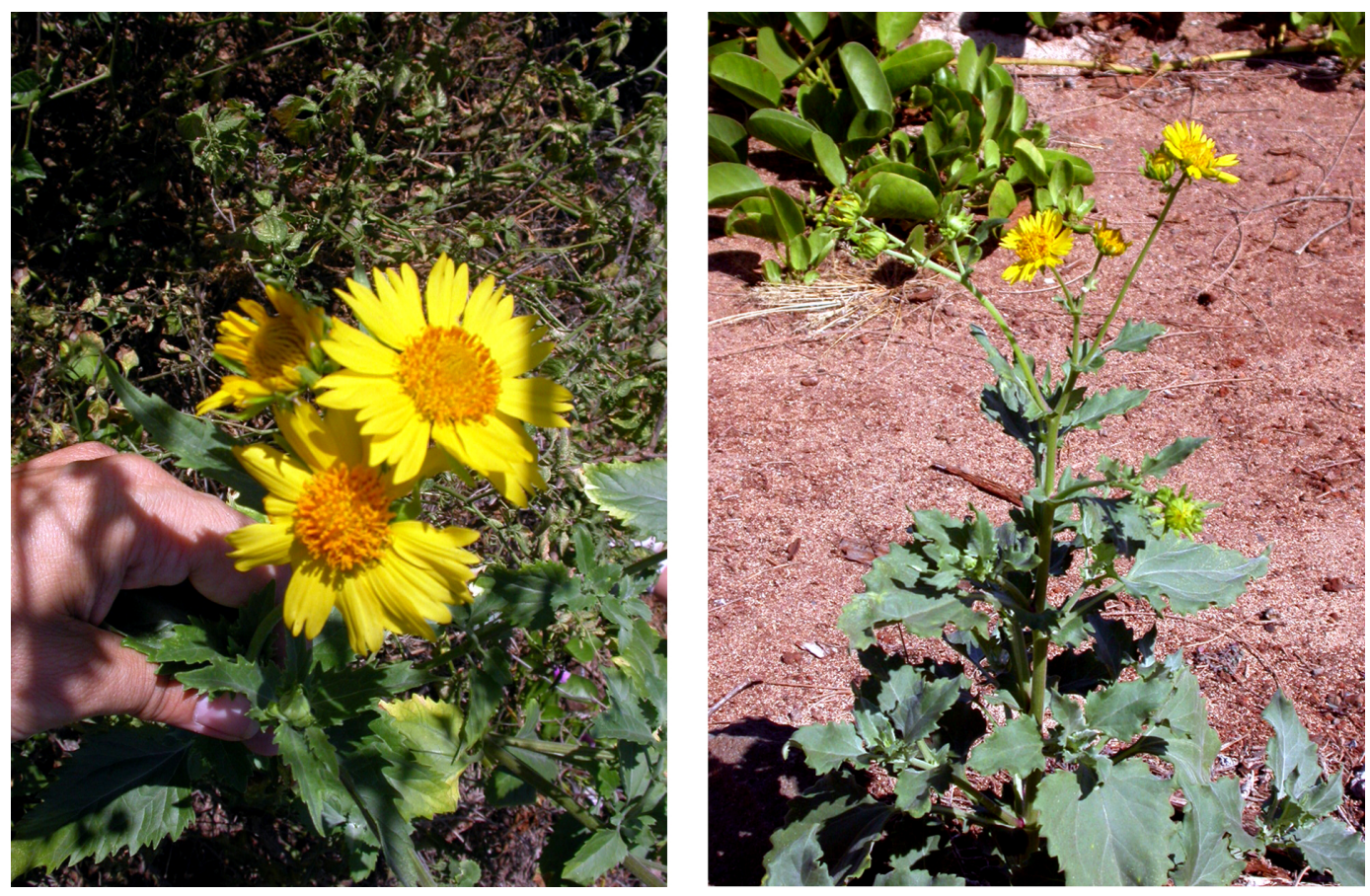

Figure 1. Verbesina encelioides (golden crownbeard) growing at Kanahā Beach Park near Kahului, Maui, Hawai‘i (photographed by D. Clements).

Common names: golden crownbeard, crownbeard, golden crown daisy, wild sunflower, cowpen daisy, girasolcito, anil del muerto, yellowtop, American dogweed, butter daisy, South African daisy.

DESCRIPTION AND ACCOUNT OF VARIATION

\section{Species Description}

An erect annual herb standing 0.3 to $1.66 \mathrm{~m}$ (Ball et al. 1951, Robbins et al. 1951, Coleman 1966, Parker 1972) (Figures 1 and 2). It is tap-rooted and has stems $2 \mathrm{~cm}$ in diameter, many of which are branched (Wagner et al. 1999). Lower leaves opposite, the upper ones alternate, ovate, or lance-shaped (Coleman 1966, Wagner et al. 1999) (Figure 2C). Leaves commonly $6 \mathrm{~cm}$ wide and $6-10 \mathrm{~cm}$ long (Coleman 1966) (Figure 2D). Both surfaces of leaves canescent-strigose, although upper surface sometimes less canescent- strigose (Wagner et al. 1999). Leaf margins typically coarsely and irregularly serrate. Petioles dilated at base to form a pair of stipulelike auricles. Radial heads solitary at ends of long peduncles or in clusters of 2-3 (Figure $2 E)$. Green phyllaries (involucral bracts) total about 15 and are subequal, linear, and $7-$ $15 \mathrm{~mm}$ long. Ray florets $10-15$ per head, 10 $25 \mathrm{~mm}$ long, and pistilate with bright yellow rays. Disk florets numerous, and corollas yellow and $8 \mathrm{~mm}$ long (Wagner et al. 1999). Ray florets three seriate with outer series often considerably larger than inner series (Coleman 1974). Seeds (achenes) grayish brown, flattened, and broadly winged along margins (Fernald 1950, Wagner et al. 1999) (Figure $2 A$ ). Seeds range in size from 5.4 to $6.7 \mathrm{~mm}$ long and 3.1-3.6 mm wide (Kaul and Mangal 1987). Seedlings bear cotyledons ranging to approximately $1.5 \mathrm{~cm}$ in length (Figure $2 B$ ). Chromosome number reported as $2 n=34$ (Solbrig et al. 1972). 

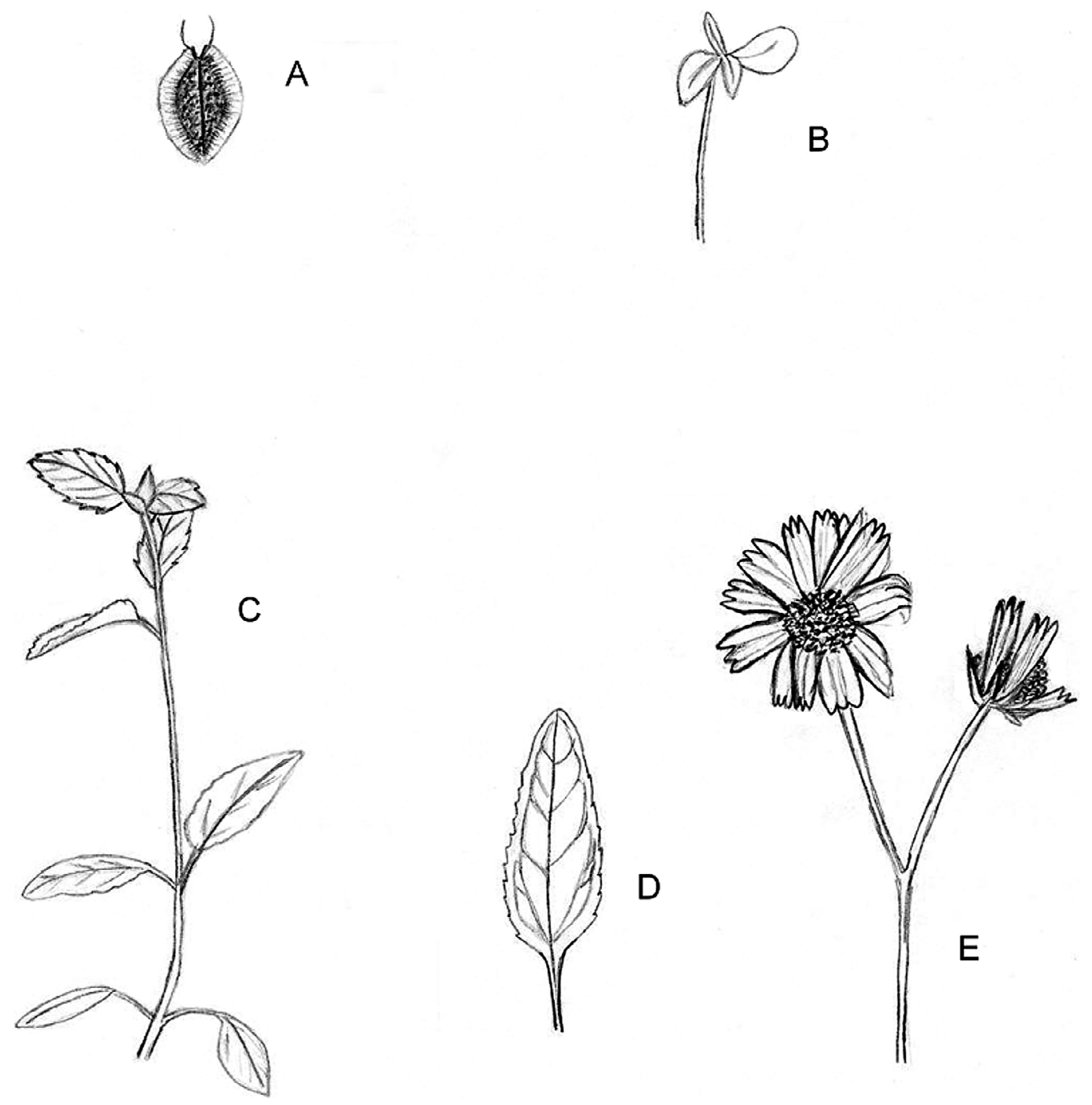

Figure 2. Life stages of Verbesina encelioides (golden crownbeard): $A$, seed; $B$, seedling, $C$, vegetative plant; $D$, leaf; $E$, flower (drawn by K. Feenstra).

\section{Distinguishing Features}

The genus Verbesina is rather diverse and contains over 200 species (Olsen 1986). Distinguishing characteristics of $V$. encelioides include its opposite (below) and alternate (above), lanceolate to deltoid leaves with a grayish undersurface, brightly colored yellow disk florets, and large yellow ray florets (10$25 \mathrm{~mm}$ ), which make the plant look like a small sunflower (Helianthus sp.) (Whistler 1995, Wagner et al. 1999). It can be differentiated from the garden sunflower (Helianthus annuus L.) by its opposite leaves on the lower part of the plant and the substantially smaller heads (Everist 1957). Both Verbesina domingensis and $V$. wrightii have narrower achene wings (Olsen 1986), and $V$. alta has more numerous ray florets typically numbering 3637 in comparison to $10-15$ for $V$. encelioides 
(Olsen 1986, Wagner et al. 1999). In addition, $V$. encelioides has the ability to form dense monotypic stands particularly along roadsides and among grasses in semiarid locations (Goel 1987) and can grow at elevations from sea level to $2,750 \mathrm{~m}$ (Walther 2004).

\section{Intraspecific Variation}

Slight variations in $V$. encelioides have been observed in different environments. In Saudi Arabia, seeds from plants grown in open and sand dune habitats were larger than seeds from plants grown in the shade and brick kiln habitats (Kaul and Mangal 1987). Seeds found in that area also exhibited differing length-breadth ratios depending on what habitat type they were found in (Kaul and Mangal 1987). The highest germination percentage was found in seeds from open and sand dune areas (Kaul and Mangal 1987).

\section{Description of Subspecies}

1. Verbesina encelioides subsp. encelioides: Auricles (ear-shaped outgrowths on each side of the petiole base) (Fernald 1950) semiovate and borne on most leaves. Achene wing apices acute and phyllaries typically over $12 \mathrm{~mm}$ long (Coleman 1966). This subspecies has a smaller distribution than $V$. encelioides subsp. exauriculata in the United States (USDA, National Resources Conservation Service 2006) and is the one found on the Islands of Hawai' $i$ and Puerto Rico in addition to many southeastern locations in North America (USDA, National Resources Conservation Service 2006).

2. Verbesina encelioides subsp. exauriculata: Auricles oblong and mainly restricted to the petioles of upper leaves. Achene wing apices obtuse and phyllaries average less than 12 $\mathrm{mm}$ long (Coleman 1966). This subspecies is not found in Hawai'i, Puerto Rico, or the Virgin Islands but is found widely throughout the central and western United States, and even in some northern states (USDA, National Resources Conservation Service 2006). Strother (2006) did not recognize $V$. encelioides subsp. exauriculata as being taxonomically distinctive.

\section{Illustrations}

See Figure 1 for a photo showing $V$. encelioides in flower at a site in Hawai'i. Additional photos of Verbesina encelioides and both subspecies are found on the USDA, National Resources Conservation Service plant database Web site (USDA, National Resources Conservation Service 2006). Figure 2 provides drawings of various anatomical features and life stages. Starr and Starr (2002) produced a series of images documenting its presence and control efforts on the Hawaiian Islands (e.g., Figure 3).

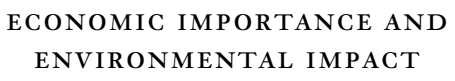

\section{Detrimental Aspects}

In Hawai'i, $V$. encelioides has caused substantial habitat degradation on Midway and Kure Atoll (K. Niethammer [U.S. Fish and Wildlife Service] and D. Smith [Hawai'i Department of Land and Natural Resources] as cited in Shluker 2002). Invasive characteristics exhibited in those areas include production of many seeds and rapid growth capabilities (John Klavitter, U.S. Fish and Wildlife Service, pers. comm., 2007). It tends to reduce habitat quality by creating a physical barrier to nesting birds, lowering nest density, and shading out native plants (Klavitter, USFWS, pers. comm., 2007). Its aggressive growth abilities inhibit the growth of native plants such as Scaevola taccada taccada (naupaka) and Ipomea pes-caprae (beach morning glory) (Shluker 2002, Walther 2004; pers. obs.). These native plants are important for the long-term habitat of nesting seabirds (Shluker 2002).

On Midway Atoll, $V$. encelioides outcompetes all 20 of the extant native plant species (John Klavitter, U.S. Fish and Wildlife Service, pers. comm., 2007). On Eastern Island (Midway Atoll, Hawai $i$ i) the plant was found to cover 30.49 ha of the 141.2 ha of total area in 1991. By 2004 the plant covered 53 ha, amounting to $38 \%$ of the island (Laniawe 2004b). Very few areas existed where native species dominated or codominated the habitat (Laniawe 2004b). On Sand Island (467.5 ha), 


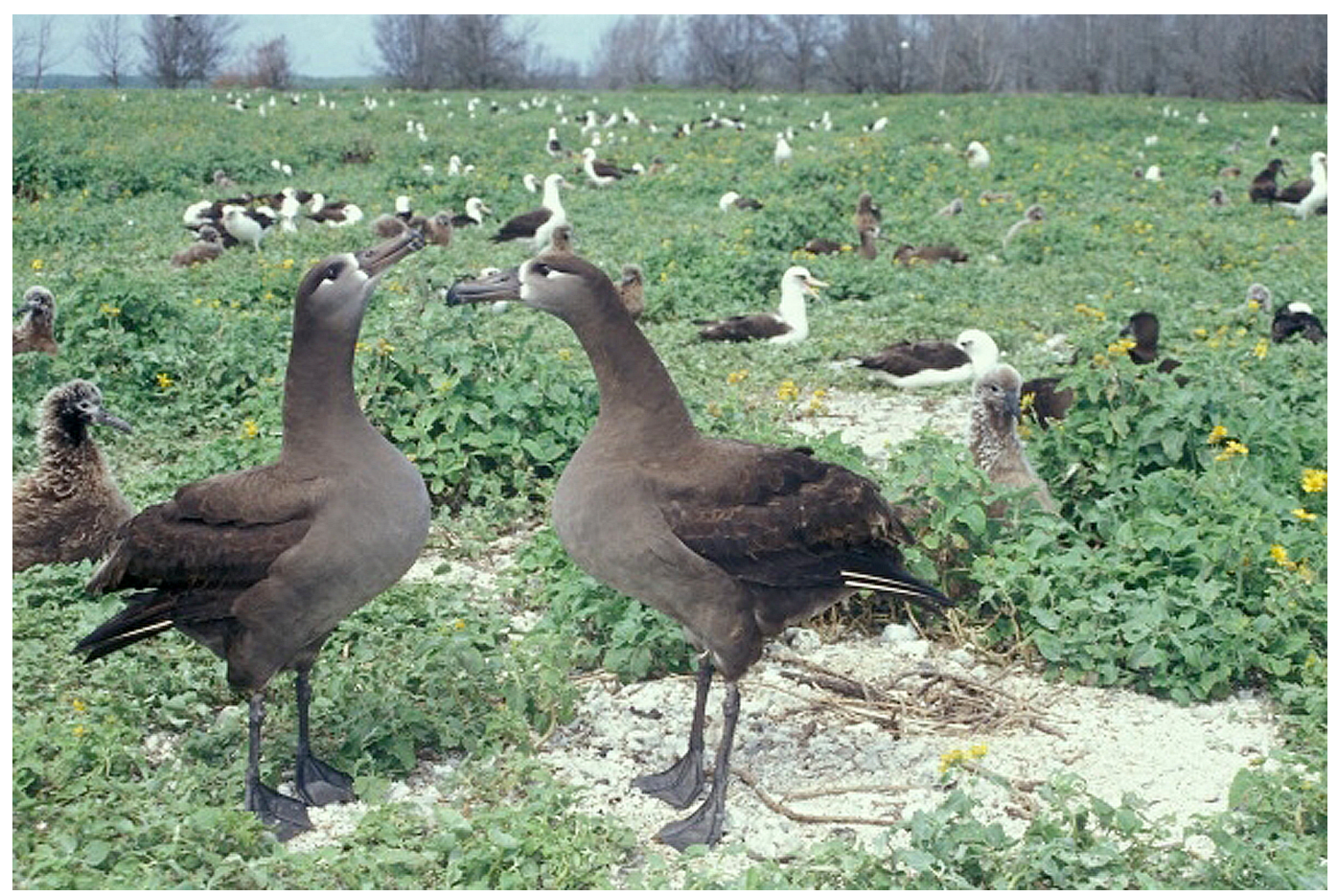

Figure 3. A field of Verbesina encelioides (golden crownbeard) on Eastern Island (Midway Atoll, Hawaii i) with a pair of black-footed albatross dancing in front of some Laysan albatross. (Photo credit: Forest and Kim Starr, 1999; used with permission.)

similar results comprised were found. In 1991, $V$. encelioides stands composed 18.2 ha, and in 2004 they comprised $60.0 \mathrm{ha}-$ an increase of $230 \%$ (Laniawe 2004a). Very few areas were found where native species codominated the habitat with $V$. encelioides (Laniawe 2004a).

Thick infestations of the plant contain few nests of any seabird species, whereas areas that have been cleared of $V$. encelioides have numerous nests of Phoebastria immutabilis (Laysan albatross), Phoebastria nigripes (black-footed albatross), Puffinus nativitatis (Christmas shearwater), and Puffinus pacificus (wedge-tailed shearwater) (VanderWerf and Rohrer 1997 as cited in Shluker 2002; John Klavitter, U.S. Fish and Wildlife Service, pers. comm., 2007). The scale of the impact of $V$. encelioides populations is evident from photographs documenting seabird colonies on atolls such as Midway Atoll (Starr and
Starr 2002) (Figure 3). Thick infestations of the plant have been observed to entangle or entrap ground-nesting and burrowing chicks (D. Smith, Hawai'i Department of Land and Natural Resources, as cited in Shluker 2002). Even when birds are not directly entangled, the plant may hinder the ability of parents to fledge young (D. Smith, Hawai'i Department of Land and Natural Resources, as cited in Shluker 2002). On Green Island, population explosions of the plant have the same effects on ground-nesting birds (Herbst and Wagner 1992). Currently, no published studies have quantified the impact this plant has on nesting bird ecosystems.

In Argentina, $V$. encelioides grows in important Ovis sp. (sheep), Bos sp. (cattle), and Sus sp. (pig) production areas (Lopez et al. 1996). It has caused livestock deaths as a result of the toxic compound galegine (3methyl-2-butenylguanine/isoamylene guani- 
dine) present in a concentration of $0.08 \%$ (Keeler et al. 1992). This compound compromises respiration, causes hemorrhaging of the heart, and ultimately results in death (Keeler et al. 1992). It is possible that the relative toxicity of the plant is dependent on its geographical area and/or growing conditions. In Australia, heavy losses of sheep have been reported as a result of $V$. encelioides toxicosis. Although livestock do not readily consume the plant, animals such as sheep, cattle, and pigs may be forced to under conditions of drought (when other food options are depleted), overstocking, or pasture dominance by $V$. encelioides (Lopez et al. 1996). Livestock are also known to consume the plant when it is mixed in with hay or other feed (Lopez et al. 1996, Keeler et al. 1986). In addition, the use of baled Arachis bypogaea L. (peanut) vines for livestock feed increases the risk of livestock poisoning because $V$. encelioides is a common weed in peanut fields (Farris et al. 2005, Farris and Murray 2006). A minimum dose of 5-6 g of dried plant material per kilogram of animal weight is considered toxic, which is a relatively high toxicity when compared with other poisonous plants in the Buenos Aires Province of Argentina. Intoxicated animals lag behind the herd within hours of consuming the plant but may recover fairly rapidly from sublethal doses (Lopez et al. 1996).

Due to its drought tolerance, $V$. encelioides is capable of establishing itself in areas where many other plants cannot grow (Al-Farraj 1990). It is known to infest many crops including Raphanus sativus L. (radish), Zea mays L. (maize), Pennisetum glaucum (L.) R. Br. (pearl millet), Triticum sp. (wheat), Oryza sp. (rice), Lens culinaris M. (gram), Brassica napus L. (rapeseed), Brassicaceae sp. (mustard), Cucumus melo L. (honeydew melon), and Arachis bypogaea L. (peanut) (Kaul and Mangal 1987, Grichar and Sestak 1998, Inderjit et al. 1999, Brandenberger et al. 2005). In particular, $V$. encelioides is problematic for peanut farmers in southern states of the United States such as Oklahoma or Texas where, over the long growing season (140-160 days), soil-applied herbicides have time to degrade, allowing broad-leaved weeds to infest the peanut crop (Grichar and Sestak 1998, Farris and Murray 2006). Peanut has prostrate growth tendencies and fairly shallow canopies, resulting in an unshaded area in the middle of crop rows that allows weeds to become competitive with the peanut plants (Walker and Wells 1989, Wilcut et al. 1995). The pattern of fruit development in peanut restricts cultivation to an early season control option because fruits develop on pegs that grow along the soil surface (Wilcut et al. 1995). Peanut farmers must use considerable amounts of soil-applied and postemergence herbicides such as bentazon and 2,4DB to control $V$. encelioides (Grichar and Sestak 1998). Such control methods can be quite costly on a large scale and have negative environmental implications.

A study quantifying the effect of time of $V$. encelioides removal on peanut yield showed a linear decline in peanut production of $2.8 \%$ per week after week 4 of peanut emergence (Farris et al. 2005). Farris et al. (2005) concluded that $V$. encelioides would have to be removed within the first 4 weeks of peanut emergence to minimize crop losses. Farris and Murray (2006) quantified the effects of various densities of $V$. encelioides on peanut yield. The relationship between peanut yield and weeds per meter in row was highly predictable, with a yield loss of $559 \mathrm{~kg} \mathrm{ha}^{-1}$ for every additional weed per meter; at 3.2 weeds $\mathrm{m}^{-1}$ of row, the maximum density tested, peanut yield was reduced by about $50 \%$. Yet this density was relatively low compared with the density of 88,750-157,500 weeds $\mathrm{ha}^{-1}$ recorded from a natural population of $V$. encelioides found in an Oklahoma peanut grower's field.

If winter conditions are mild, $V$. encelioides causes further damage to crops due to yearround persistence and suitability as a host for other crop pests (Grichar and Sestak 1998). Verbesina encelioides is a highly favored host for thrips species that act as vectors of the tomato spotted wilt virus (TSWV) (Grichar and Sestak 1998). Because the plants are often found in clusters, the visibility of the flowers makes the plants very attractive to thrips (Mitchell and Smith 1996), and Yudin et al. 
(1988) recommended managing $V$. encelioides to help prevent the spread of the virus. In Hawai' $i$, the plant is a reservoir host for both the TSWV and the Impatiens necrotic spot virus (Cho et al. 1986). The TSWV virus is vectored by a minimum of nine species of thrips; two of these, Franklinella fusca Hinds and $F$. occidentalis Pergande, are the primary species coupled with southern Texas peanut crops (Mitchell et al. 1990). These species grow from first instar to adult on the leaves of $V$. encelioides (Mitchell and Smith 1996). Verbesina encelioides subsp. encelioides is also host to Phenacoccus solani Ferris, the solanum mealybug, which infests potato tubers (ScaleNet 2006).

In addition to competition for resources, it is speculated that $V$. encelioides possesses allelopathic properties that may be detrimental to plant growth, apparently involving phenolic compounds (Goel 1987, Inderjit et al. 1999). Verbesina encelioides forms dominant monotypic stands on wastelands and roadsides and is found to be gregarious among grasses in semiarid locations (Goel 1987). As a result, researchers have speculated that the plant may be allelopathic. Currently, only two published studies have been conducted to understand the interference mechanism of this weed.

Goel (1987) investigated the allelopathic properties of the plant in a soil-free setting. She studied the effect of stem, floral, and leaf extracts and root leachates of $V$. encelioides on the germination and seedling growth of four common weed species in India and found that leaf and floral extracts had higher phytotoxic abilities when compared with the root leachates and stem extracts. As a result, Goel (1987) suggested allelopathy as its mechanism of interference success. However, it was still necessary to look at interactions of the potential allelochemicals with soil (Inderjit et al. 1999). Upon entry into soil the bioactive concentrations of allelochemicals are measured by their sorption, fixation, leaching, and chemical and microbial degradation in soil (Dalton et al. 1983, Cheng 1995, Wardle and Nilsson 1997, Tongma et al. 1998, Blum 1999). Allelopathic activities of plant leachates can be detoxified or enhanced by physical, chemical, and biological soil factors (Cheng 1995, Schmidt and Ley 1999).

Inderjit et al. (1999) performed bioassays to study the effect of soils amended with different concentrations of $V$. encelioides root leachate on the growth of radish (Raphanus sativus $\mathrm{L}$.) species and found that the addition of full strength and half strength leachate decreased root and shoot growth of radish seedlings. In addition, the total level of phenolics present in the soil amended with the leachate was greater than that of the control. High performance liquid chromatography (HPLC) was used to analyze the root leachate and both quantitative and qualitative differences in phenolic peaks were found. Thus it was determined that the plant was synthesizing phenolics and/or storing them. As a result, Inderjit et al. (1999) affirmed Goel's (1987) suggestion that allelopathy might enhance the competitive ability of $V$. encelioides.

Feenstra (2007) conducted bioassays and chemoassays for a rhizosphere solution derived from $V$. encelioides seedlings grown under soil-free conditions. Results from the bioassay using radish seedlings were no different than those from the control $(P<.05)$. The chemoassay failed to detect any of the following phenolics in the rhizospheric solution: caffeic acid, vanillic acid, syringic acid, p-coumaric acid, p-hydroxybenzoic acid, protocatechuic acid, gallic acid, sinaptic acid, m-coumaric acid, o-coumaric acid, transcinnamic acid, chlorogenic acid, and ferulic acid. It is possible that the seedlings tested by Feenstra (2007) did not reach sufficient size to produce phenolics with discernable allelopathic effects, or that the allelopathic effect acts only through plant litter produced by $V$. encelioides. Clearly further work is required to quantify potential allelopathic effects and investigate possible mechanisms.

\section{Beneficial Aspects}

In a study of Indian plants with possible medicinal value, flavonol 3,7-diglycosides (phenols) were found in the floral extracts of 
$V$. encelioides (Glennie and Jain 1980). The phenolic residues of flavonol glycosides are thought to be effective scavengers of reactive oxygen species in vitro and could possibly serve to suppress oxidative DNA damage (Buchgraber and Karaali 2005). In addition to this, the phenolic moieties may also lower the risk of cancer and oxidized LDL cholesterol carriers and thereby reduce the risk of heart disease and wrinkled skin (Buchgraber and Karaali 2005).

Hartwell (1967) reported that $V$. encelioides is also used as treatment for cancer and warts. Native Americans, particularly the Hopi, Navajo, Kayenta, Ramah, and Zuni Indian tribes also have many uses for the plant. Different parts of the plant were used to treat fever, itch, spider bites, stomachaches, cramps, worms, rattlesnake bites (Anonymous 2006), hemorrhoids, ulcers, and digestive disorders (Arellano 1997). The same Native Americans used the plant for soap, food, and spiritual applications (University of Michigan 2006). Extracts of the plant are also reported to have anti-inflammatory properties, useful for treating either gum sores or hemorrhoids (Ledlow 1999, as cited in Shluker 2002).

Verbesina encelioides is the food plant for the bordered patch butterfly, Chlosyne lacinia (Struttman 2004). The bordered patch butterfly is an attractive butterfly with a wingspan of roughly $5 \mathrm{~cm}$, fairly common in the native range of $V$. encelioides. Adult butterflies feed on nectar of the flowers and lay eggs on the underside of the leaves (Struttman 2004). When the caterpillars hatch, they first eat the underside of the leaves. Older larvae consume the leaves and the stems. The distribution of the butterfly overlaps the distribution of the plant, but the plant is found in a wider area of the United States (Struttman 2004).

\section{Regulatory Aspects}

Verbesina encelioides is not listed as a federal noxious weed in the United States, nor is it listed in the federal seed act (Shluker 2002). However, numerous state weed control programs have been implemented to manage $V$. encelioides populations. Although the plant is not listed officially as a noxious weed, it is considered by many people (particularly peanut farmers) to be noxious due to its competitive abilities and toxic properties (Mitchell and Smith 1996).

\section{GEOGRAPHICAL DISTRIBUTION}

Native to southeastern North America and parts of Central and South America (Walther 2004, Strother 2006), $V$. encelioides is currently found on a number of major Pacific islands. In Hawai' $i$ it is found on all of the main islands except Ni'ihau (Wagner et al. 2005): Kure, Midway Atoll, Pearl and Hermes Reef, Kaui'i, O’ahu, Moloka'i, Lāna'i, Maui, Kaho'olawe, and Hawai' $i$ are its recorded locations (Wagner et al. 2005). In particular, it is found in great abundance on the Northwestern Hawaiian Islands of Kure and Midway Atoll. However, it is not documented to occur on any other Pacific islands. For example, to date, $V$. encelioides is not found in Samoa, Tonga, Tahiti, Fiji, Guam, Belau, the Marquesas, nor in the Virgin Islands (Whistler 1995, Wagner et al. 2005).

Verbesina encelioides has now successfully established on all major continents with the exception of Antarctica. It has successfully naturalized in many warm regions of the world: the southern U.S. states, parts of South America, the Bahamas, Cuba, Dominican Republic, Puerto Rico, Saudi Arabia, India, Ethiopia, Morocco, Botswana, Namibia, Israel, and Australia (Coleman 1966, AlFarraj 1990, Keeler et al. 1992, Lopez et al. 1996, Arellano 1997, Walther 2004, European and Mediterranean Plant Protection Organization 2006, Solomon et al. 2006, USDA National Resources Conservation Service 2006). There are also reports of $V$. encelioides in more temperate regions of the world such as Denmark, Germany, Switzerland, and Sweden (Tutin et al. 1976). It occurs in at least 24 U.S. states and in most cases is not considered native (Shetler and Skog 1978, Keeler et al. 1992, Shluker 2002, Strother 2006). Detailed distribution (United States only) maps for Verbesina encelioides (both subspecies) are available from the USDA Natural Resources Conservation Service (2006). In Australia, V. encelioides is found 
in large numbers particularly in Queensland, New South Wales, and Northern Victoria (Oelrichs and Vallely 1981).

НАВITAT

\section{Climatic Requirements and Limitations}

Verbesina encelioides is found in a wide variety of habitats with differing temperatures, climates, and elevations. In its native range in North and South America, particularly in Mexico and the states of Texas, Arizona, and North Dakota, it is found at elevations of up to 2,750 m (Walther 2004). Typically, the plant is found in dry and disturbed areas (Walther 2004). Seeds of $V$. encelioides survive and remain viable under climactic conditions that include drought and high temperatures (Kaul and Mangal 1987). Seeds can lie dormant when soils are desiccated to below $5 \%$ moisture content and when temperatures are between 38 and $46^{\circ} \mathrm{C}$ (Kaul and Mangal 1987).

Germination success of $V$. encelioides appears to be largely determined by soil structure, temperature, and nutrient composition (Al-Farraj et al. 1988). A laboratory study of Saudi Arabian populations found that day temperature of $18^{\circ} \mathrm{C}$ and night temperature of $8^{\circ} \mathrm{C}$ produced almost $100 \%$ germination if seeds were in petri dishes, and a day temperature of $28^{\circ} \mathrm{C}$ and night temperature of $14^{\circ} \mathrm{C}$ produced almost $100 \%$ germination of seeds sown in sand (the preferred substratum of the plant). Seeds did not germinate in clay soil regardless of temperature. Also, seeds did not germinate at higher day temperatures, such as $41^{\circ} \mathrm{C}$. Seed germination percentage decreased with the depth the seed was sown; seeds had the highest germination percentage when sown on the surface of the soil. Seeds sown below a depth of $2 \mathrm{~cm}$ did not germinate (Al-Farraj et al. 1988).

\section{Habitat and Resource Requirements}

Verbesina encelioides is a mesophytic plant (AlFarraj 1990) and thus does not need large amounts of water. According to the Arizona Department of Water Resources Web site, the plant is drought tolerant such that once established, it requires only monthly watering
(Radford et al. 1968, Al-Farraj 1990, Arizona Department of Water Resources 2006). Near Pearsall and Duval, Texas, populations of the plant were found growing in loamy fine sand (fine-loamy, mixed, hyperthermic Aridic Haplustalfs) with a $\mathrm{pH}$ of 6.8 to 7.2 and an organic matter content of less than 1\% (Grichar and Sestak 1998). A similar preference for sandy soil is seen in other areas, such as Oklahoma and Hawai'i (McCoy 1987; pers. obs.). Maximum seed germination occurs in open and sand dune areas (Kaul and Mangal 1987, Al-Farraj 1990). The ideal soil moisture content for seed germination was $21 \%$; any deviation from that level resulted in decreased seed germination (Kaul and Mangal 1987). Soil chemistry also plays a role in seed germination. Seeds failed to germinate $(0 \%$ germination) in clay soils that contained at least $30 \%$ more magnesium, iron, or potassium than the sandy soil tested; the lack of germination was attributed to osmotic inhibition via the abundant ions present in clay substrates (Al-Farraj et al. 1988). Kaul and Mangal (1987) also found that soil type influenced seed size; seeds were heaviest from plants grown in open sand dune habitats. Thus, disturbed areas with a relatively sandy substrate and satisfying its climatic tolerance range are vulnerable to invasion by $V$. encelioides.

\section{Ecosystem and Community Types Invaded}

Verbesina encelioides has generally invaded open sandy areas such as railway tracks, roadsides, and wastelands subject to disturbance (Kaul and Mangal 1987, European and Mediterranean Plant Protection Organization 2006, U.S. Geological Survey 2006). It flourishes in humid, hot areas with cool winters (Kaul and Mangal 1987). In Hawai'i most populations have been found in coastal or disturbed areas close to sea level, but $V$. encelioides has also been found at altitudes as high as 2,805 $\mathrm{m}$ (Wagner et al. 1999). The largest populations have developed on the Northwestern Hawaiian Islands of Kure and Midway Atoll, where $V$. encelioides has displaced native plants such as Scaevola taccada (naupaka) and Ipomoea pes-caprae (beach morning glory) (Shluker 2002, Walther 2004). Accord- 
ing to John Klavitter (USFWS, Midway Atoll Wildlife Refuge, pers. comm., 2007) on Midway Atoll all habitats are prone to $V$. encelioides invasion. However, humus-rich soils allow the plant to grow taller and quicker. As a result, in such areas, the plant invades more aggressively and is more successful. Verbesina encelioides has also invaded many agroecosystems (see section on Economic Importance and Environmental Impact).

In the plateau near Taif, Saudi Arabia, $V$. encelioides is a prominent weed in three plant communities $(1,630-1,680 \mathrm{~m})$, forming 5$15 \%$ of the plant cover (Zayed and ElKaremy 1989). These communities are characterized by an open landscape and sandy plains sparsely traversed by shallow wadis (dried-up riverbeds). The soil in these communities is coarse-textured with a surface covered by rock fragments. Water resources are limited (approximately $208 \mathrm{~mm} \mathrm{yr}^{-1}$ ), and wind erosion was moderate (Zayed and El-Karemy 1989).

\section{HISTORY}

The botanist William Hillebrand reported the presence of $V$. encelioides on Maui in the mid-1800s (Carr 2006). By 1888, it was found on all major Hawaiian Islands except Hawai'i, $\mathrm{Ni}^{\mathrm{i}}$ ihau, and the Northwestern Hawaiian Islands, and it is now found on all the main Hawaiian Islands except $\mathrm{Ni}$ i'ihau (Wagner et al. 2005). The plant's ability to form dense, fairly monotypic stands has enabled it to become prominent in many areas of the Hawaiian archipelago. Verbesina encelioides was first documented in the Northwestern Hawaiian Islands on Kure Atoll in 1959 (Woodward 1972), where it was thought to have arrived via bulldozers used by the military, then increased greatly in abundance, and is now a high priority for weed control (Wagner et al. 2005). Some progress in the management of $V$. encelioides populations has been made in the Northwestern Hawaiian Islands as well as in other areas such as Kanahā Beach Park in Maui (Forest Starr, U.S. Geological Survey, pers. comm., 2005; John Klavitter, USFWS, pers. comm., 2007), but because of high seed densities in the soil, continued effort is re- quired to manage these populations. In Australia, there is no record of the date of introduction, but current records indicate that the plant is naturalized in a number of locations including southern and central Queensland, New South Wales, and Northern Victoria (Oelrichs and Vallely 1981).

\section{PHYSIOLOGY}

In areas receiving little rain, with soil moisture below 5\%, seeds will lie dormant until the first heavy rains (Kaul and Mangal 1987). Al-Farraj (1990) observed that under controlled water conditions $V$. encelioides began germinating $24 \mathrm{hr}$ after sowing in pots of sand and reached $50 \%$ germination after 5 days. Kaul and Mangal (1987) documented the phenology of $V$. encelioides in Bathinda, India. The radicle protruded within $64 \mathrm{hr}$ and attained a length of 5-6 mm within the first 4 days. Following this, the radicle growth slowed and the plumule elongated quickly and forcibly separated the cotyledons. Chlorophyll developed rapidly in the cotyledons; within the first 4 or 5 days the leaves turned from deep yellow to dark green (Kaul and Mangal 1987). Cotyledons wilted after 26 to 28 days and the seedling gained independence with the appearance of its first leaves. Flowering was initiated 102-118 days after sowing and fruit set occurred 10-12 days later (Kaul and Mangal 1987). Flowering generally occurs during warmer months, particularly after heavy rains (Goel 1987). The month of flowering varies depending on location; for example, in India flowering occurs from August to October (Goel 1987), and in North Dakota from July to September (U.S. Geological Survey 2006). In Hawai $i$, the plant flowers for a longer period of time, typically between April and November (K. Niethammer, USFWS, as cited in Shluker 2002). The plants die off between December and February on Midway Atoll, Hawai'i (John Klavitter, USFWS, pers. comm., 2007).

\section{REPRODUCTION}

Verbesina encelioides exhibits a high potential for reproduction. The plant exhibits efficient self- and cross-pollination. It reproduces 
solely by winged seeds that are dispersed by light winds (Kaul and Mangal 1987). On Midway Atoll, Hawai'i, plants produced 300-350 seeds per flower head (K. Niethammer, USFWS, as cited in Shluker 2002). Dispersed seeds typically remain directly under or near the parent plant (K.R.F., pers. obs.). Al-Farraj et al. (1988) found that maximum germination in Saudi Arabia occurred at the soil surface in open sand dune areas with soil moisture of $21 \%$.

\section{POPULATION DYNAMICS}

Few studies of the population dynamics of $V$. encelioides have been conducted. Further population dynamic studies accounting for total seed production of a plant would be useful in quantifying population dynamics and the invasive potential of $V$. encelioides. Seeds lie dormant until proper conditions exist for germination, typically after the first heavy rains of the season (Kaul and Mangal 1987). Populations tend to flourish in humid, hot regions (Kaul and Mangal 1987). Growth and survival of seedlings is promoted by high relative humidity levels (Helen Lindahl, unpubl. data). Established plants are drought tolerant and can withstand high temperatures; once established the plants require watering only once per month (Radford et al. 1968, AlFarraj 1990, Arizona Department of Water Resources 2006). As a result, $V$. encelioides flourishes in hot, arid climates where disturbance of the native vegetation has occurred. In those environments, the plant tends to form pure colonies (Goel 1987).

\section{RESPONSE TO MANAGEMENT}

Shluker (2002) reported on methods developed to manage $V$. encelioides in the Northwestern Hawaiian Islands by Ken Niethammer, an assistant refuge manager on Midway Atoll. These methods included flower head removal in sealed bags, taproot removal by hand pulling, mowing (to keep plants from flowering), and continual monitoring (K. Niethammer, USFWS, as cited in Shluker 2002). For relatively small populations, removal of flower heads is a good first step, preventing the formation of a seed bank in newly disturbed soil. Removal of taproots must be done carefully to ensure complete removal. Hand-pulled plants must be disposed of to avoid the possibility of rerooting, which is quite possible, particularly in the event of subsequent rainfall. Mowing has been effective on large, level areas on Midway Atoll, and although plants may survive it is an effective measure in forestalling flowering and seed production. Removal efforts must be carried out at monthly intervals because the disturbance created by the removal of weeds provides a potential habitat for seed germination and establishment (K. Niethammer, USFWS, as cited in Shluker 2002). After an area has been cleared three times, it is still necessary to monitor the area monthly; replanting native vegetation may be important for restoration of disturbed sites (Shluker 2002). A native bunchgrass, Eragrostis variabilis (Gaud.) Steud., has been planted in some areas where $V$. encelioides was controlled (John Klavitter, USFWS, pers. comm., 2006). On Kure Atoll, V. encelioides control efforts in some areas have been deliberately minimized under the theory that populations will naturally decline after an initial eruptive phase (D. Smith, Hawai'i Department of Land and Natural Resources, as cited in Shluker 2002). John Klavitter (USFWS, pers. comm., 2006) found that after about 2 yrs of control most of the seed bank was eliminated and thereafter only occasional hand pulling was required every 6 months.

Chemical control is aided by an initial mechanical weeding of the plants to allow smaller plants to receive sufficient amounts of the chemical (K. Niethammer, USFWS, as cited in Shluker 2002). Rodeo (Dow AgroSciences, Indianapolis, Indiana) (active ingredient: glyphosphate) is used to control populations of $V$. encelioides on Midway Atoll in a concentration of $1.17-2.0 \mathrm{ml}$ per liter of water (K. Niethammer, USFWS, as cited in Shluker 2002). Herbicides only need to be applied twice, and then the area requires monitoring only once. On Kure Atoll, a 2\% solution of Roundup (Monsanto, St. Louis, Missouri) (active ingredient: glyphosphate) controlled populations of $V$. encelioides grow- 
ing in the midst of native plant species (Smith and Woodside, unpubl. data, cited in Shluker 2002). For monospecific stands of $V$. encelioides, a combination of Roundup and Garlon 3A (Dow AgroSciences, Indianapolis, Indiana) was found to be effective (D. Smith, Hawai'i Department of Land and Natural Resources, as cited in Shluker 2002). More recently John Klavitter (USFWS, pers. comm., 2006) also reported success on Midway Atoll using Garlon 4 (active ingredient: triclopyr), Aquamaster (Monsanto, St. Louis, Missouri) (active ingredient: glyphosate), or SpeedZone (PBI/Gordon, Kansas City, Missouri) (active ingredients: carfentrazone; 2,4D; mecoprop; dicamba).

In southern Texas, eight postemergence herbicides were evaluated for use on $V$. encelioides, alone or in combination (Grichar and Sestak 1998). The study indicated that imazapic and imazethapyr provided sporadic control, with efficacy varying with variable moisture conditions and large weed size. The best options for postemergence control were benzaton, lactofen, pyridate, 2,4-DB, and aciflourfen or pyridate plus 2,4-DB (Grichar and Sestak 1998). When used alone, bentazon (1.12 kg ha-1) and 2,4-DB (0.28 kg ha $\left.{ }^{-1}\right)$ achieved at least $90 \%$ control of $V$. encelioides, and aciflouren $\left(0.42 \mathrm{~kg} \mathrm{ha}{ }^{-1}\right)$ and pyridate provided only $80 \%$ control (Grichar and
Sestak 1998). Brandenberger et al. (2005) achieved $100 \%$ control of $V$. encelioides using the sulfonylurea herbicide halosulfuron in a honeydew melon (Cucumus melo L.) crop. However, only about $70 \%$ control of $V$. encelioides was achieved with another sulfonylurea herbicide, prosulfuron (CGA-15205) in a Texas peanut crop (Grichar et al. 2000). To maximize crop yields, Farris et al. (2005) recommended removal of $V$. encelioides before the fourth week of crop emergence. For preemergence control, ethalfluralin applied preplanting incorporated followed by imazapic or lactofen provided $100 \%$ control of $V$. encelioides (Grichar and Sestak 1999, as cited in Shluker 2002).

Other alternatives for controlling $V$. encelioides include controlled burns or the use of salt water (seawater). In areas such as the Northwestern Hawaiian Islands controlled burning is not possible due to the presence of ground-nesting birds (Shluker 2002). Preliminary work was done using seawater that showed some browning of leaves following application of seawater, but further research on the efficacy of this treatment is required (Shluker 2002).

No biological control agents are currently available for $V$. encelioides. At least 14 fungal pathogens have been recorded in association with $V$. encelioides (Table 1 ) that could po-

TABLE 1

Fungal Pathogens Associated with Verbesina encelioides

\begin{tabular}{lll}
\hline \hline Fungus & \multicolumn{1}{c}{ Location(s) } & \multicolumn{1}{c}{ Reference } \\
\hline $\begin{array}{l}\text { Cercospora verbesinicola } \\
\text { Coleosporium viguierae }\end{array}$ & Argentina & Crous and Braun (2003) \\
& Arizona, Texas & Anonymous (1960), Cummins (1964), \\
Yohem et al. (1985) & Anonymous (1960) \\
Colletotrichum sp. & Arizona & Simmonds (1966) \\
Oidium sp. & Australia & Anonymous (1960) \\
Phymatotrichum omnivorum & Texas & Anonymous (1960) \\
Plasmopara balstedii & Texas & Anonymous (1960) \\
Puccinia abrupta & Texas & Ministerio do Meio Ambiente (2006) \\
Puccinia cnici-olaracei & Brazil & Ciferri (1961), Yohem et al. (1985), \\
Puccinia cognate & Arizona, Texas, & Anonymous (1960) \\
Puccinia diaziana & Dominican Republic & Ministerio do Meio Ambiente (2006) \\
Puccinia schilaena & Brazil & Lindquist (1982) \\
Puccinia ximenesiae & Argentina & Cummins (1978) \\
Sphaerotheca fuliginea & Texas & Simmonds (1966), Amano (1986) \\
\hline
\end{tabular}


tentially be tested for efficacy and host specificity.

\section{NATURAL ENEMIES}

As described previously, $V$. encelioides is the food plant for the bordered patch butterfly, Chlosyne lacinia (Struttman 2004). Verbesina encelioides subsp. encelioides is a host for Phenacoccus solani, the solanum mealybug (ScaleNet 2006). Thrips species also feed on $V$. encelioides (Mitchell and Smith 1996, Grichar and Sestak 1998). The impact of these arthropods on $V$. encelioides remains unstudied, and other arthropods such as aphids have been observed feeding on the plant (D.R.C., unpubl. obs.). Fungi occurring on $V$. encelioides are discussed in the previous section (see Table 1). There are no known mammalian predators of $V$. encelioides, and it has been found to be toxic to many mammals (Keeler et al. 1992).

\section{PROGNOSIS}

Verbesina encelioides could readily colonize other Pacific islands beyond the Hawaiian archipelago, if it has not already. The climates of most of the Pacific islands are conducive to the establishment of $V$. encelioides and thus it is possible that the plant could infest many vulnerable ecosystems. The plant's ability to withstand drought and flourish through a wide range of elevations and climatic conditions gives it a competitive edge against many other species. Rapid growth, high seed production, long period of seed dormancy, high germination rate, and potential allelopathic effects of $V$. encelioides together increase the likelihood of it establishing in new environments. This is evidenced by the plant's spread from its native range in the southern United States to locations as disparate as Morocco, India, the Bahamas, and Australia. However, further research is needed to develop a better understanding of the invasive potential of $V$. encelioides, quantifying its population dynamics and impacts on natural ecosystems and also its actual and potential invasion pathways as mediated by human trade and other activities.

Once the plant is established, it is very difficult and costly to remove. The lack of staff and funding for management of existing and emergent populations of $V$. encelioides are major factors that contribute to the invasive success of the weed. There seem to be few natural predators of $V$. encelioides, and the impact of the predators or pathogens on the plant is not well researched. Although its only documented occurrence in the Pacific is within the Hawaiian Islands, $V$. encelioides may already occur on other islands as an incipient invader. It is essential that measures be taken to prevent the establishment of the plant on other Pacific islands.

\section{ACKNOWLEDGMENTS}

We are grateful to Stephen Darbyshire of Agriculture and Agri-Food Canada for thoroughly reviewing an early version of the manuscript.

\section{Literature Cited}

Al-Farraj, M. M. 1990. Effect of drought on growth of Xanthium brasilicum Veil., Verbesina encelioides Benth. and Datura innoxia Mill. seedlings. Phyton 51:89-93.

Al-Farraj, M. M., H. Hassan, and R. AlDosoky. 1988. Germination studies on Verbesina encelioides (Cav) Benth. et Hook ex. A. Gray (Asteraceae). J. Arid Environ. 15:169-174.

Amano, K. 1986. Host range and geographical distribution of the powdery mildew fungi. Japan Scientific Societies Press, Tokyo.

Anonymous. 1960. Index of plant diseases in the United States. U.S. Dep. Agric. Agric. Handb. 165:1-531.

- 2006. Native American ethnobotany, University of Michigan, http://herb.umd .umich.edu/ (accessed 25 May 2006).

Arellano, A. 1997. Herbal medicine in northern New Mexico. Herbs for Health March/April 1997:46-52.

Arizona Department of Water Resources. 2006. Low water use and drought tolerant plants, Arizona Department of Water Resources, http://www.azwater.gov/dwr/ (accessed 25 May 2006).

Ball, W. S., A. S. Crafts, R. N. Raynor, and W. W. Robbins. 1951. Principals of weed 
control. Pages 13-15 in Weeds of California. Originally published in Weed Control, California Agricultural Extension Service Circular No. 97.

Blum, U. 1999. Designing laboratory plant debris-soil bioassays: Some reflections. Pages 17-23 in Inderjit, K. Dakshini, and C. Foy, eds. Principles and practices in plant ecology: Allelochemical interactions. CRC Press, Boca Raton, Florida.

Brandenberger, L. P., R. E. Talberg, R. P. Wiedenfeld, and J. W. Shrefler. 2005. Effects of halosulfuron on weed control in commercial honeydew crops. Weed Technol. 19:346-350.

Buchgraber, M., and A. Karaali. 2005. Compilation of standardized analytical methods for the analysis of active ingredients in functional foods. European Commission, Directorate-General Joint Research Centre, Institute for Reference Materials and Measurements. http://www.irmm.jrc .be/html/publication...ports/publications/ EUR21831ENcomplete.pdf (accessed 13 April 2006).

Carr, G. D. 2006. Manoa campus plants. University of Hawai'i, http://www.botany .hawaii.edu/Faculty/Carr/page25.htm (accessed 22 June 2006).

Cheng, H. 1995. Characterization of the mechanisms of allelopathy: Modeling and experiential approaches. Pages 132-141 in Inderjit, K. Dakshini, and F. Einhellig, eds. Allelopathy: Organisms, processes, and applications. American Chemical Society, Washington, D.C.

Cho, J. J., R. F. L. Mau, D. Gonsalves, and W. C. Mitchell. 1986. Reservoir weed hosts of tomato spotted wilt virus. Plant Dis. 70:1014-1017.

Ciferri, R. 1961. Mycoflora Domingensis Integrata. Quadermo 19:1-539.

Coleman, J. R. 1966. A taxonomic revision of section Ximenesia of the genus Verbesina L. (Compositae). Am. Midl. Nat. 76:475-481.

. 1974. Verbesina section Ximenesia (Compositae): Biosystematics and adaptive variation. Am. J. Bot. 61:25-35.

Crous, P. W., and U. Braun. 2003. Mycosphaerella and its anamorphs. Centraalbureau voor Schimmelcultures, Utrecht, The Netherlands.
Cummins, G. B. 1964. Uredinales of the Big Bend National Park and adjacent areas of Texas. Southwest. Nat. 8:181-195.

- 1978. Rust fungi on legumes and composites in North America. University of Arizona Press, Tucson.

Dalton, B. R., U. Blum, and S. B. Weed. 1983. Allelopathic substances in ecosystems: Effectiveness of sterile soil components in altering recovery of ferulic acid. J. Chem. Ecol. 9:1185-1201.

European and Mediterranean Plant Protection Organization (EPPO). 2006. EPPO Reporting Service. http://archives.eppo .org/EPPOReporting/2006/Rse-0603.pdf (accessed 8 June 2006).

Everist, S. 1957. Common weeds of farms and pastures. A. H. Tucker, Government Printer, Brisbane, Australia.

Farris, R. L., C. J. Gray, D. S. Murray, and L. M. Verhalen. 2005. Time removal of crownbeard (Verbesina encelioides) on peanut yield. Weed Technol. 19:380-384.

Farris, R. L., and D. S. Murray. 2006. Influence of crownbeard (Verbesina encelioides) densities on peanut (Arachis bypogaea) yield. Weed Technol. 20:627-632.

Feenstra, K. R. 2007. Investigation of the allelopathic potential of Verbesina encelioides. B.S. thesis, Trinity Western University, Langley, British Columbia.

Fernald, M. L. 1950. Gray's manual of botany. 8th ed. American Book Company, New York.

Glennie, C. W., and S. C. Jain. 1980. Flavonol 3,7-diglycosides of Verbesina encelioides. Phytochemistry 19:157-158.

Goel, U. 1987. Allelopathic effects of Verbesina encelioides Cav. Ann. Arid Zone 26:287-291.

Grichar, W. J., and D. Sestak. 1998. Control of golden crownbeard (Verbesina encelioides) in peanut (Arachis hypogaea) with postemergence herbicides. Peanut Sci. 25:39-43.

Grichar, W. J., D. C. Sestak, K. Brewer, and B. Minton. 2000. Weed control with CGA-152005 and peanut (Arachis bypogaea) response. Weed Technol. 14:218222.

Hartwell, J. L. 1967. Plants used against cancer: A survey. Lloydia (Cinci.) 30:379-436. 
Herbst, D. R., and W. L. Wagner. 1992. Alien plants on the Northwestern Hawaiian Islands, Pages 189-224 in C. P. Stone, C. W. Smith, and J. T. Tunison, eds. Alien plant invasions in native ecosystems of Hawaii: Management and research. University of Hawai'i Press, Honolulu.

Inderjit, C. Asakawa., and K. M. M. Dakshini. 1999. Allelopathic potential of Verbesina encelioides root leachate in soil. Can. J. Bot. 77:1419-1424.

Kaul, M. L., and P. D. Mangal. 1987. Phenology and germination of crownbeard (Verbesina encelioides). Weed Sci. 35:513-518.

Keeler, R. F., D. C. Baker, and K. E. Panter. 1992. Concentration of galegine in Verbesina encelioides and Galega officianalis and the toxic and pathologic effects induced by the plants. J. Environ. Pathol. Toxicol. Oncol. 11:11-17.

Keeler, R. F., A. E. Johnson, and L. S. Stuart. 1986. Toxicosis from and possible adaptation to Galega officinalis in sheep and the relationship to Verbesina encelioides toxicosis. Vet. Hum. Toxicol. 28:309-315.

Laniawe, L. 2004a. Midway Atoll National Wildlife Refuge: GIS maps of Sand, Eastern, and Spit Islands. Report for the U.S. Fish and Wildlife Service, 10 May. University of Hawai'i at Hilo, Hilo. Available from Hawai'i Division of Forestry and Wildlife, Honolulu.

. 2004b. Midway Atoll National Wild-

life Refuge: GIS maps of Eastern and Spit Islands, Part II. Report for the U.S. Fish and Wildlife Service, 3 December. University of Hawai'i at Hilo, Hilo. Available from Hawai'i Division of Forestry and Wildlife, Honolulu.

Lindquist, J. C. 1982. Royas de la Republica Argentina y zonas limitrofes. Instituto $\mathrm{Na}$ cional de Technología Agropecuaria, Buenos Aires, Argentina.

Lopez, T. A., C. M. Campere, R. Chayer, B. Cosentino, and M. Caracino. 1996. Experimental toxicity of Verbesina encelioides in sheep and isolation of galegine. Vet. Hum. Toxicol. 38:417-419.

McCoy, D. 1987. Oklahoma wildflowers. Ebsco Graphics, Oklahoma City, Oklahoma.

Ministerio do Meio Ambiente. 2006. Cata- logue of the species of plant rust fungi (Uredinales) of Brazil. http://www .jbrj.gov.br/publica/uredinales/Brazil_ Catalogue1drevisado.pdf (accessed 9 June 2006).

Mitchell, F., and J. Smith. 1996. Influence of Verbesina encelioides (Asterales: Asteraceae) on thrips (Thysanoptera: Terbrantia) populations and tomato spotted wilt virus epidemics in South Texas peanut fields. J. Econ. Entomol. 89:1593-1600.

Mitchell, F., J. Smith, and H. Hichland. 1990. Insecticidal suppression of thrips as a means of reducing tomato spotted wilt virus disease incidence in peanut. Pages 8-9 in R. S. Halliwell, ed. Tomato spotted wilt virus disease of peanut: A summary of research. Tex. Agric. Exp. Sta. Prog. Rep. CPR-4691.

Oelrichs, P., and P. Vallely. 1981. Isolation of galegine from Verbesina encelioides. J. Nat. Prod. 44:754-755.

Olsen, J. 1986. Revision of Verbesina Section Verbesina (Asteraceae: Heliantheae). Brittonia 38:362-368.

Parker, K. F. 1972. An illustrated guide to Arizona weeds. University of Arizona Press, Tucson.

Radford, A. E., H. E. Ahles, and C. R. Bell. 1968. Manual of the vascular flora of the Carolinas. University of North Carolina Press, Chapel Hill.

Robbins, W. W., M. K. Bellue, and W. S. Ball. 1951. Weeds of California. California Department of Agriculture, Sacramento.

ScaleNet. 2006. Queries, ScaleNet, http:// www.sel.barc.usda.gov/scalenet/scalenet .htm (accessed 25 May 2006).

Schmidt, S., and R. Ley. 1999. Microbial competition and soil structure limit the expression of allelochemicals in nature. Pages 339-351 in Inderjit, K. Dakshini, and L. Foy, eds. Principles and practices in plant ecology: Allelochemical interactions. CRC Press, Boca Raton, Florida.

Shetler, S. G., and L. E. Skog. 1978. A provisional checklist of species for Flora North America (revised). Missouri Botanical Garden, Saint Louis.

Shluker, A. 2002. Harmful non-indigenous species (HNIS) report for Verbesina encelioides. Hawaiian Ecosystems at Risk 
Project, http://www.hear.org/index.html (accessed 8 June 2006).

Simmonds, J. H. 1966. Host index of plant diseases in Queensland. Queensland Department of Primary Industries, Brisbane.

Solbrig, O. T., D. W. Kyhos, M. Powell, and P. H. Raven. 1972. Chromosome numbers in Compositae. VIII: Heliantheae. Am. J. Bot. 59:869-878.

Solomon, T., H. Snyman, and G. Smit. 2006. Soil seed bank characteristics in relation to land use systems and distance from water in arid rangeland of southern Ethiopia. S. Afr. J. Bot. 72:263-271.

Starr, F., and K. Starr. 2002. Plants of Hawaii. Hawaiian Ecosystems at Risk Project (HEAR), http://www.hear.org/starr/index .html (accessed 22 June 2006).

Strother, J. L. 2006. Verbesina. Pages 106-111 in Flora of North America Editorial Committee, ed. Flora of North America north of Mexico. Vol. 21. Oxford University Press, New York.

Struttman, J. 2004. Butterflies of North America: Bordered patch (Chlosyne lacinia), Northern Prairie Wildlife Research Centre, http://www.npwrc.usgs.gov/index .htm (accessed 25 May 2006).

Tongma, S., K. Kobayashi, and K. Usui. 1998. Allelopathic activity of Mexican sunflower (Tithonia diversiflora) in soil. Weed Sci. 46:432-437.

Tutin, T. G., V. H. Heywood, N. A. Burges, D. M. Moore, D. H. Valentine, S. M. Walters, and D. A. Webb, eds. 1976. Flora Europaea. Vol. 4. Plantaginaceae to Compositae (and Rubiaceae). Cambridge University Press, Cambridge, England.

USDA Natural Resources Conservation Service (NRCS). 2006. Plants database, U.S. Department of Agriculture, http:// plants.usda.gov/index.html (accessed 25 May 2006).

U.S. Geological Survey. 2006. Native wildflowers of the North Dakota grasslands, http://www.npwrc.usgs.gov/ resource/plants/wildflwr/species/verbence .htm (accessed 25 May 2006).
Wagner, W. L., D. R. Herbst, and D. H. Lorence. 2005. Flora of the Hawaiian Islands Web site, http://ravenel.si.edu/botany/ pacificislandbiodiversity/hawaiianflora/ index.htm (accessed 31 May 2006).

Wagner, W. L., D. R. Herbst, and S. H. Sohmer. 1999. Manual of the flowering plants of Hawai'i. Rev. ed. University of Hawai'i Press, Honolulu.

Walker, R. H., and L. W. Wells. 1989. Bristly starbur (Acanthospermum hispidum) interference in peanuts (Arachis bypogaea). Weed Sci. 37:196-200.

Walther, M. 2004. A guide to Hawaii's coastal plants. Mutual Publishing, Honolulu, Hawai'i.

Wardle, D. A., and M.-C. Nilsson. 1997. Microbe-plant competition, allelopathy and arctic plants. Oecologia (Berl.) 109:291-293.

Whistler, W. A. 1995. Wayside plants of the islands: A guide to the lowland flora of the Pacific islands. Isle Botanica, Honolulu, Hawai'i.

Wilcut, J. W., A. C. York, W. J. Grichar, and G. R. Wehtje. 1995. The biology and management of weeds in peanut (Arachis bypogaea). Pages 207-244 in H. E. Patee and H. T. Stalker, eds. Advances in peanut science. American Peanut Research and Education Society, Inc., Stillwater, Oklahoma.

Woodward, P. 1972. The natural history of Kure Atoll, Northwestern Hawaiian Islands. Atoll Res. Bull. 164.

Yohem, K. H., G. B. Cummins, and R. L. Gilbertson. 1985. Revised list and host index of Arizona rust fungi. Mycotaxon 22:451-468.

Yudin, L. S., B. E. Tabashnik, J. J. Cho, and W. C. Mitchell. 1988. Colonization of weeds and lettuce by thrips (Thysanoptera: Thripidae). Environ. Entomol. 17:522526.

Zayed, K., and A. El-Karemy. 1989. Vegetation between taif and El-Shafa highland (Asir Mountains, Saudi Arabia). Feddes Repert. 100:661-672. 